\title{
'Role of Serum Cholinesterase and 5-Nucleotidase Enzyme Activity in the Diagnosis of Alcoholic and Non-Alcoholic Liver Disease and Compared With Healthy Subjects of Rajasthan'
}

\author{
Shalini Vyas ${ }^{1 *}$, Dr. R.K.Vyas ${ }^{2}$, Hemlata Sharma ${ }^{3}$ \\ Department of Biochemistry, Sardar Patel Medical College, Bikaner, Rajasthan, India
}

DOI: $10.36348 /$ sjmps.2019.v05i12.017

| Received: 19.12.2019 | Accepted: 26.12.2019 | Published: 30.12.2019

*Corresponding author: Shalini VYAS

\section{Abstract}

Aim of the study was to find out the role of biochemical markers in diagnosis of alcoholic liver disease and non-alcoholic liver disease and compared these values with healthy subjects of Rajasthan. Total 300 subjects were selected in which 200 were selected as patients group (alcoholic liver disease (ALD) and non-alcoholic liver disease (NALD) group) and 100 were normal healthy subjects. Total 100 alcoholic liver disease patients in which 91 patients were male and 09 patients were female. In non- alcoholic liver disease group 55 males and 45 females are enrolled. Patients were distributed age wise. Serum cholinesterase and serum 5-nucleotidase were estimated by commercially available kit on spectrophotometer. Serum cholinesterase level is 2822.99 \pm 716.51 in ALD patients. In NALD patients, serum cholinesterase level was $4299.95 \pm 1014.76$ and in control group mean serum cholinesterase level was $6303.99 \pm 977.59$. Pvalue was statically highly significant. ( $\mathrm{P} \leq 0.0001$ ), as well as serum 5-nucleotidase level was $25.89 \pm 5.77$ and $17.70 \pm$ 4.43 in ALD and NALD respectively. In control group mean level of serum 5-nucleotidase was 9.851 \pm 3.24 . (P $\leq 0.0001)$. We conclude that serum cholinesterase level was decreased in both disease group, whereas serum 5-nucleotidase level is increased in both disease groups. Both parameters are liver specific and specific test for alcohol induced or alcoholic liver disease as well as in non-alcoholic liver disease. Both parameters can be used as a marker of liver disease. it was concluded that serum cholinesterase and 5' -nucleotidase are better diagnostic marker then the conventional liver function test that are raised in other liver disease also.

Keywords: ALD, NALD spectrophotometer, cholinesterase, 5-nucleotidase.

Copyright @ 2019: This is an open-access article distributed under the terms of the Creative Commons Attribution license which permits unrestricted use, distribution, and reproduction in any medium for non-commercial use (NonCommercial, or CC-BY-NC) provided the original author and source are credited.

\section{INTRODUCTION}

In our body liver is a largest vital organ. In India liver disease is very common as liver is having a broad variety of functions. It is also known as hepatic disorder [1]. In world it is major cause of morbidity and mortality. Multiple functions are performed by liver [2]. Liver responsible for a wide range of vital functions like blood detoxification, blood purification, plasma protein synthesis, bile production and carbohydrate, fats and protein metabolism[3].Physicians have long sought an accurate and inexpensive means of identifying persons who consume excessive amounts of ethyl alcohol. It is reported that medically diagnosed alcoholics persons can be differentiated reliably from non-alcoholic's persons using clinical laboratory tests. So, distinguish between alcoholic liver disease from non-alcoholic liver disease is more important implications for treatment and management [4].
Liver disease is diagnosed by large number of conventional liver function tests like Bilirubin levels, Transaminase levels, alkaline phosphatase, Total Proteins, Serum Albumin level and Albumin/Globulin ratio. They are performed for last many years, but they do not have $100 \%$ sensitivity and $100 \%$ specificity.

Routine parameters of liver function tests are raised many times in non-liver diseases, like Transaminase levels in cardiac disease, Alkaline phosphatase levels in bone diseases etc. So, there is a need for a test which should be more sensitive and specific for diagnosed liver diseases. Cholinesterase enzyme is produced in liver, its assay is important in liver diseases. In mammalian cells 5'-nucleotidase (5'NT) is present [5] which is an intrinsic membrane glycoprotein. 
Many studies have been done in the past but it requires more studies to prove its usability of this diagnostic marker in the diagnosis of liver diseases.

In liver cirrhosis, alcoholic liver disease, chronic hepatitis $\mathrm{C}$, chronic alcoholism, neoplasms of liver and bile ducts, benign biliary disease the enzyme activity of 5-NT is increased, but it reaches its high level in the presence of biliary stasis[6,7]. $5 \mathrm{NT}$ is also a sensitive marker for hepatic metastasis. In liver metastasis, the diagnostic level of $5 \mathrm{NT}$ is superior to other liver enzymes. Increased levels of 5 NT activities are found in $92 \%$ of patient with obstructive jaundice, $70 \%$ of patients with parenchymal liver disease and 81 $\%$ of patients with hepatic metastasis $[8,9]$. It is also reported that serum $5 \mathrm{NT}$ is clinically useful for differential diagnosis of hepatobiliary and osseous diseases; the enzyme activity has been increased only in hepatobiliary disease [10].

According to mohd.et al. serum 5'-NT showed elevations in mean level of three-fold in viral hepatitis, 2.5 folds increased in alcoholic liver disease and twofold in cirrhosis. It is helpful to estimate the serum 5'NT, and it should be clinically useful for differential diagnosis of hepatobiliary diseases and its degree of involvement [11].

In blood stream serum cholinesterase enzyme is secreted and produced by liver. Serum cholinesterase estimation is reflecting hepatocellular damage and according to Turkey L[12]. It is regarded as sensitive indicator of liver diseases [13]. The low level of serum cholinesterase reflects impaired enzyme synthesis by liver in the absence of genetic cause or known inhibitors. Serum cholinesterase level is decreased in many liver diseases like liver cirrhosis, viral hepatitis, alcoholic liver disease, malignancies of liver diseases. After liver transplant monitoring of liver functions, is promoted by the measurement of serum cholinesterase activity hence enzyme activity has been promoted as an indicator of prognosis and diagnosis values in patients with liver diseases [14].

Our study was conducted to find out the usefulness assay of 5 , nucleotidase and serum cholinesterase in the diagnosis of alcoholic and nonalcoholic liver disease.

\section{MATERIALS AND METHODS}

The present study was conducted on 300 subjects (aged between 30-70 years of both sexes) in the Biochemistry Department of Sardar Patel Medical College and Medicine and Gastroenterology Department of PBM hospital. 100 patients of alcoholic liver disease and 100 patients of non-alcoholic disease were clinically confirmed liver damage (by routine investigations and fibrin scan) admitted in medicine wards. 100 normal persons were selected as control group. Blood collected in a clean and dry test tube. Allow samples to clot for 2 hours at room temperature before centrifugation. Collect the supernatant and carried out the assay immediately. Serum cholinesterase and serum 5-nucleotidase was performed with the help of commercially available kits on spectrophotometer.

Design of Study- A Case-control analytical study

\section{Setting}

This study was carried out in the Department of Biochemistry in collaboration with the Department of General medicine and Gastroenterology at S.P. Medical College and Associated group of P.B.M. Hospitals, Bikaner. All participants completed a medical history form and provided informed consent.

\section{Study Population}

Study included 300 subjects. 200 were study group and 100 were control group subjects clinically diagnosed liver damage alcoholic and non-alcoholic patients. Patients who presented in Medicine and Gastro Departments of PBM hospital with history suspicious of liver damage and their liver function tests are abnormal, their fibrosis were diagnosed with fibrin scan. In this study $73 \%$ patients were males and $27 \%$ were females. Patients were distributed age wise in which $43 \%$ patients were between $30-50$ years and $57 \%$ patients were between 51-70 years.

\section{Study Period \& Study Approval}

Present study was done from 2016 to 2019. The Institutional Ethical Committee at the Sardar Patel Medical College and Associated Group of P.B.M. Hospitals, Bikaner, and Rajasthan, India approved the study. The Developmental Research Committee at the Rajasthan University of Health Sciences, Jaipur, India also approved the study.

\section{Study Protocol}

The following criteria are undertaken for the selection of the patients in the study: -

\section{INCLUSION CRITERIA}

The patients having abnormal liver functions test with impairs radiological finding, fibrin scan report with physician confirmation were included in this study. Controls were healthy individuals, age and sex matched without any major illness.

\section{EXCLUSION CRITERIA}

The patients with age between 30-70 years, having acute infection, chronic malnutrition, poisoning from organophosphates, will be excluded.

Females having pregnancy or using oral contraceptive pills and Patients taking drugs which affecting levels of trace elements and antioxidant status were excluded from the study 
Observation tables

Table-1: Sex wise distribution of patients

\begin{tabular}{|l|l|l|l|}
\hline Gender & $\begin{array}{c}\text { CONTROL } \\
(\mathbf{N}=\mathbf{1 0 0})\end{array}$ & $\begin{array}{l}\text { ALCOHOLIC LIVER DISEASE } \\
(\text { ALD) PATIENTS (N=100) }\end{array}$ & $\begin{array}{l}\text { NON- ALCOHOLIC LIVER DISEASE } \\
(\text { NALD) PATIENTS (N=100) }\end{array}$ \\
\hline Male & 62 & 91 & 55 \\
\hline Female & 38 & 9 & 45 \\
\hline Total & 100 & 100 & 100 \\
\hline
\end{tabular}

Table-2: Age wise distribution of patients and control

\begin{tabular}{|c|c|c|c|c|c|}
\hline \multirow[t]{2}{*}{ GROUPS } & \multicolumn{2}{|c|}{ AGE GROUP 30-50 YEARS } & \multicolumn{2}{|c|}{ AGE GROUP 51-70 YEARS } & \multirow[t]{2}{*}{ TOTAL } \\
\hline & MALE & FEMALE & MALE & FEMALE & \\
\hline ALD & 47 & 5 & 44 & 4 & 100 \\
\hline NALD & 11 & 23 & 44 & 22 & 100 \\
\hline CONTROL & 30 & 25 & 32 & 13 & 100 \\
\hline
\end{tabular}

Table-3: Socio-demographic distribution of patients and control group

\begin{tabular}{|l|l|l|l|l|l|}
\hline \multirow{2}{*}{ GROUPS } & \multicolumn{2}{|c|}{ LITERATE } & \multicolumn{2}{c|}{ ILLITERATE } & TOTAL \\
\cline { 2 - 5 } & HINDU & MUSLIM & HINDU & MUSLIM & \\
\hline ALD & 64 & 17 & 7 & 12 & 100 \\
\hline NALD & 74 & 11 & 7 & 8 & 100 \\
\hline CONTROL & 75 & 14 & 9 & 2 & 100 \\
\hline
\end{tabular}

Table-4: Comparison of serum cholinesterase and serum 5'-nucleotidase level in male and female patients group with control [age 30-50 years]

\begin{tabular}{|l|l|l|l|l|l|l|l|}
\hline \multirow{2}{*}{ PARAMETERS } & \multicolumn{3}{|c|}{ MALE (30-50 YEARS) } & \multicolumn{3}{c|}{ FEMALE (30-50 YEARS) } & \multirow{2}{*}{ P -VALUE } \\
\cline { 2 - 7 } & ALD & NALD & CONTROL & ALD & NALD & CONTROL & \\
\hline SERUM CHE & $2877.69 \pm$ & $4086.72 \pm$ & $6276.41 \pm$ & $2802.18 \pm$ & $4195.46 \pm$ & $6348.57 \pm$ & 0.0001 \\
& 713.59 & 1328.18 & 908.82 & 631.65 & 934.04 & 1078.58 & \\
\hline SEUM 5'NT & $24.92 \pm$ & $18.89 \pm$ & $9.67 \pm$ & $28.61 \pm$ & $18.05 \pm$ & $9.53 \pm$ & 0.0001 \\
& 5.48 & 4.5 & 3.13 & 5.46 & 4.95 & 3.24 & \\
\hline
\end{tabular}

Table-5: Comparison of serum cholinesterase and serum 5'-nucleotidase level in male and female patients group with control [age 51-70 years]

\begin{tabular}{|l|l|l|l|l|l|l|l|}
\hline \multirow{2}{*}{ PARAMETERS } & \multicolumn{3}{|c|}{ MALE (51-70 YEARS) } & \multicolumn{3}{c|}{ FEMALE (51-70 YEARS) } & P -VALUE \\
\cline { 2 - 8 } & ALD & NALD & CONTROL & ALD & NALD & CONTROL & \\
\hline SERUM CHE & $2758.14 \pm$ & $4236.30 \pm 936.30$ & $6378.59 \pm$ & $2919.59 \pm$ & $4643.08 \pm 1066.68$ & $6098.30 \pm$ & 0.0001 \\
& 725.03 & & 1090.09 & 972.84 & & 652.02 & \\
\hline SEUM 5'NT & $26.69 \pm$ & $17.53 \pm$ & $10.16 \pm$ & $25.23 \pm$ & $17.06 \pm$ & $10.08 \pm$ & 0.0001 \\
& 6.01 & 4.25 & 3.34 & 6.62 & 4.34 & 3.55 & \\
\hline
\end{tabular}
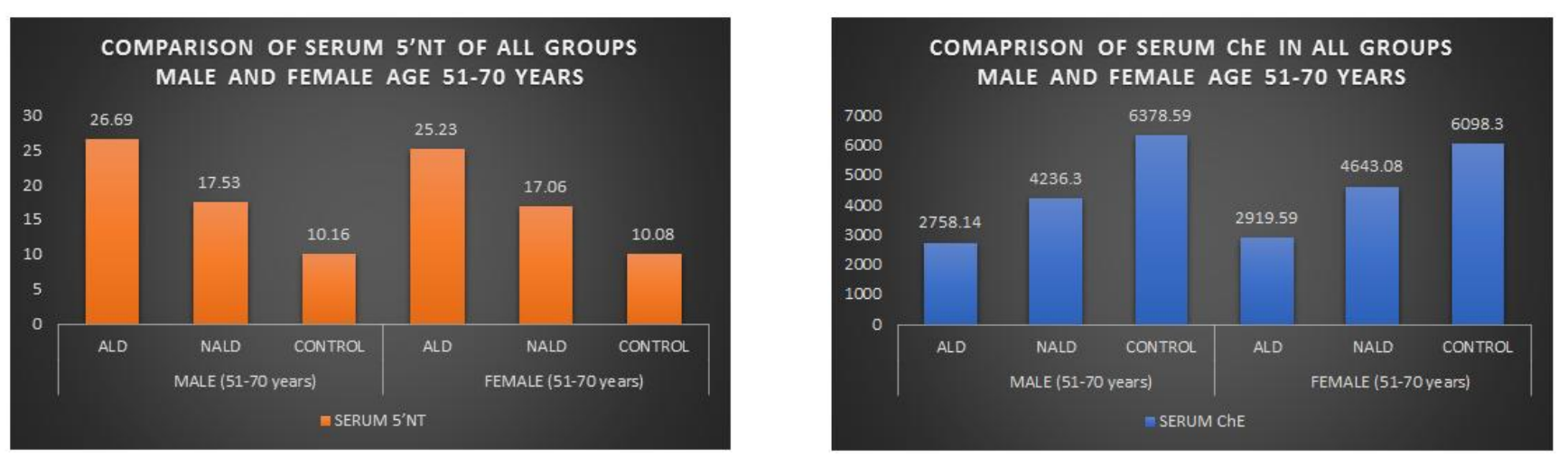
Table-6: Comparison of alcoholic liver disease and non-alcoholic liver disease with control

\begin{tabular}{|l|l|l|l|l|l|}
\hline Parameters & $\begin{array}{l}\text { Biological } \\
\text { reference } \\
\text { values }\end{array}$ & $\begin{array}{l}\text { Alcoholic liver } \\
\text { disease (n=100) } \\
\text { mean+/-S.D. }\end{array}$ & $\begin{array}{l}\text { Non-alcoholic liver } \\
\text { disease (n=100) } \\
\text { mean+/-S.D. }\end{array}$ & $\begin{array}{l}\text { Control }(\mathrm{n}=100) \\
\text { mean+/-S.D. }\end{array}$ & P value \\
\hline $\begin{array}{l}\text { Serum } \\
\text { Cholinesterase }\end{array}$ & $\begin{array}{l}3930-11500 \\
(\mathrm{IU} / \mathrm{L})\end{array}$ & $2822.99 \pm 716.51$ & $4299.95 \pm 1014.76$ & $6303.99 \pm 977.59$ & $<0.0001$ \\
\hline $\begin{array}{l}\text { Serum } \\
\text { 5-Nucleotidase }\end{array}$ & 2-10(IU/L) & $25.89 \pm 5.77$ & $17.70 \pm 4.43$ & $9.851 \pm 3.24$ & $<0.0001$ \\
\hline
\end{tabular}

COMPARISON OF SERUM CHE IN DISEASE GROUP AND CONTROL GROUP

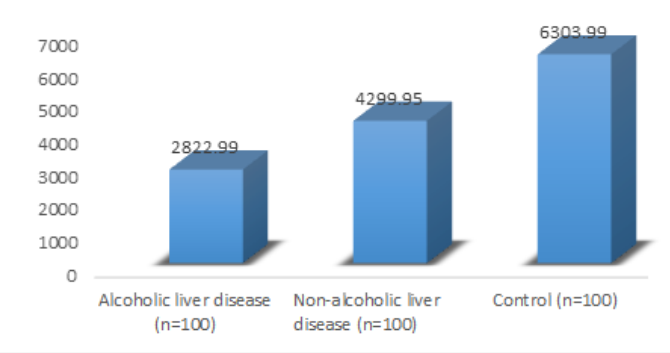

COMPARISON OF SERUM 5'NT IN DISEASE GROUP AND CONTROL GROUP

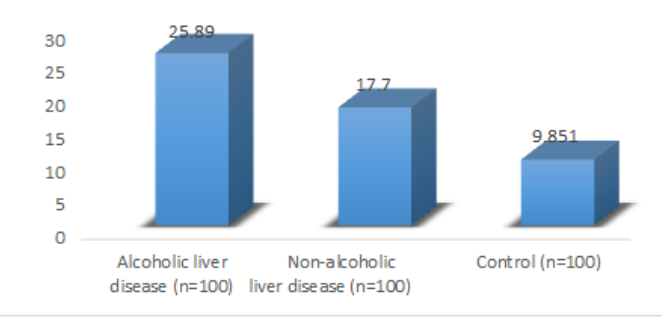

Table-7: Correlation of serum cholinesterase level with serum 5'nt of alcoholic liver disease

\begin{tabular}{|l|l|}
\hline R value & 5-NT \\
\hline Serum cholinesterase & -0.78707 \\
\hline
\end{tabular}

\section{CORRELATION BETWEEN SERUM ChE AND} 5'NT IN ALD PATIENTS

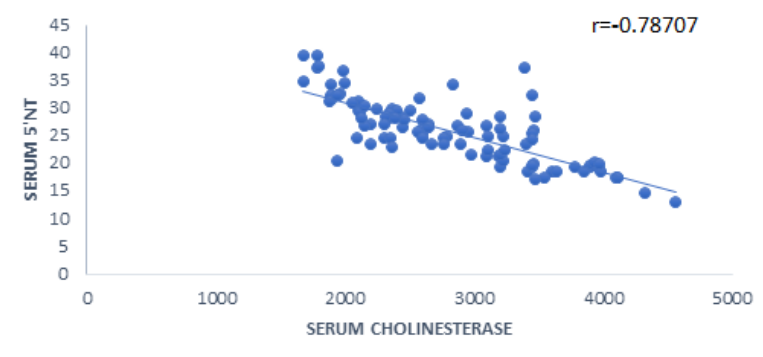

Table-8: Correlation of serum cholinesterase level with serum 5'nt of non-alcoholic liver disease

\begin{tabular}{|l|l|}
\hline $\mathbf{R}$ value & 5-NT \\
\hline $\begin{array}{l}\text { Serum } \\
\text { cholinesterase }\end{array}$ & -0.67257 \\
\hline
\end{tabular}

\section{CORRELATION BETWEEN SEUM ChE AND} 5'NT IN NALD PATIENTS

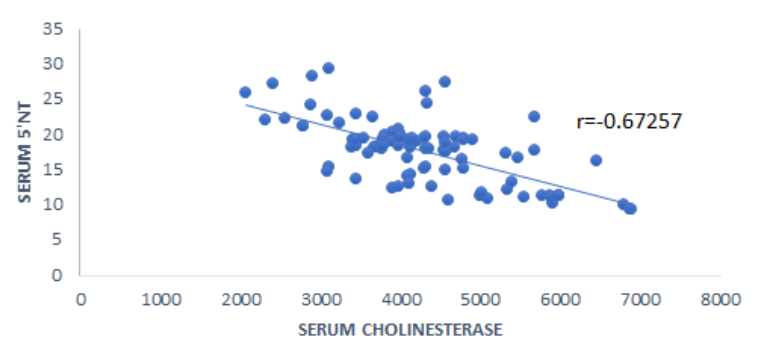

\section{RESULTS}

Table no 1,2,3 showing age, sex wise and socio-demographic distribution of patients and control subjects. Table no. 4 showing comparison of serum cholinesterase and serum 5'-nucleotidase level in male and female patient group with control [age 30-50 years]. The mean value of serum cholinesterase in male ALD, NALD and control group was 2877.69 \pm 713.59 , $4086.72 \pm 1328.18,6276.41 \pm 908.82$ respectively in age group 30-50 years. In females the mean value of serum Cholinesterase was $2802.18 \pm 631.65$ in ALD, $4195.46 \pm 934.04$ in NALD and $6348.57 \pm 1078.58$ in controls of same age group. The mean value of serum nucleotidase level in males was $24.92 \pm 5.48$ in ALD, $18.89 \pm 4.5$ in NALD and $9.67 \pm 3.13$ in control of $30-50$ years age group. In females the mean value of serum 5 'NT was $28.61 \pm 5.46$ in ALD, $18.05 \pm 4.95$ in NALD, and $9.53 \pm 3.24$ in control of same age group. The pvalue is highly significant $<0.0001$.

Table no. 5 showing comparison of serum cholinesterase and serum 5'-nucleotidase level in male and female patient group with control [age 51-70 years]. The mean value of serum cholinesterase in male ALD, NALD and control group was 2758.14 \pm 725.03 , $4236.30 \pm 936.30,6378.59 \pm 1090.09$ respectively in age group 51-70 years. In females the mean value of serum Cholinesterase was 2919.59 \pm 972.84 in ALD, $4643.08 \pm 1066.68$ in NALD, and 6098.30 \pm 652.02 in controls of same age group. The mean value of serum nucleotidase level in males was $26.69 \pm 6.01$ in ALD, $17.53 \pm 4.25$ in NALD, and $10.16 \pm 3.34$ in control of 5170 years age group. In females the mean value of serum 5 'NT was $25.23 \pm 6.62$ in ALD, $17.06 \pm 4.34$ in NALD and $10.08 \pm 3.55$ in control of same age group. The pvalue is highly significant $<0.0001$. 
Table no.-6 showing the comparison of alcoholic liver disease and non-alcoholic liver disease with control with biological reference value of both enzymes. Serum Cholinesterase biological references value is 3930-11500 (IU/L). Serum 5-Nucleotidase biological reference value is $2-10$ (IU/L). The serum cholinesterase level was decreased in both liver disease patients. The mean value of serum cholinesterase of all alcoholic patients $(\mathrm{n}=100)$ was 2822.99 \pm 716.51 , $4299.95 \pm 1014.76$ in all non-alcoholic patients $(n=100)$ and $6303.99 \pm 977.59$ in all control group $(n=100)$.

5' nucleotidase levels were increased in both alcoholic and non-alcoholic liver disease patients. The mean value of serum $5^{\prime} \mathrm{NT}$ of all alcoholic patients $(n=100)$ was $25.89 \pm 5.77,17.70 \pm 4.43$ in all nonalcoholic patients $(\mathrm{n}=100)$ and $9.851 \pm 3.24$ in all control group $(n=100)$. P-value was found to be significant when compared with healthy subjects. $(\mathrm{P} \leq 0.001)$. So, it was clearly observed that 5 'nucleotidase and serum cholinesterase is of great diagnostic importance in alcoholic and non-alcoholic liver disease patient in comparison to the conventional liver function test.

Table no.-7 depicts the correlation coefficient analysis between mean serum cholinesterase level and serum 5'nucleotidase level in alcoholic liver disease. Serum ChE was positively correlated with serum 5'NT (r-0.78707).

Table no. 8 showing the coefficient analysis between mean serum cholinesterase level and serum 5 'nucleotidase level in non-alcoholic liver disease. Serum ChE was positively correlated with serum 5'NT $(r=-67257)$.

\section{DISCUSSION}

Liver function tests (LFTs) are used for the monitoring of patients with hepatic dysfunction that include SGOT, SGPT, ALP, bilirubin and albumin. But abnormal results found in patients with clinical problems other than liver dysfunction [15].

Hepatocytes synthesize cholinesterase and released them into the blood [16]. The serum cholinesterase activity is reduced in liver dysfunction due to reduced synthesis. When other serum enzymes had been compared with the clinical assessment of liver functions, it is in contrast. Because other enzymes activity is increased during liver dysfunction as a result of enhanced released from their cellular sources followed by cell membrane damage [17].

A family of enzymes Cholinesterase catalyses the hydrolysis of the neurotransmitter acetylcholine into choline and acetic acid. For following activation, it is necessary to allow a cholinergic neuron to return to its resting stage. The two types of cholinesterase's: (a)
Acetylcholinesterase (AchE), also known as RBC and erythrocyte cholinesterase's or acetylcholine acetyl hydrolase. They are mainly found in the blood and neural synapses and existing in various molecular forms. The majority of AchE occurs as a tetrameric in mammalian brain, G4 form with smaller amounts of a monomeric G1 form. (b) Pseudocholinesterase, also known as plasma cholinesterase, butyryl cholinesterase or acyl choline acyl hydrolase, which is found primarily in the liver [18].

Estimation of the serum cholinesterase activity was firstly suggested by McArdle [19], as a useful marker for differentiating hepatic from post-hepatic jaundice. Cholinesterase activity is an assessment indicator for liver function in liver disease patients it suggests. Few studies are available regarding the value of cholinesterase in evaluating liver function.

Keeping in view the finding of earlier researchers, our study was performed to evaluate the effectiveness of serum cholinesterase to correctly diagnose patients of liver dysfunction. The study was conducted on 100 alcoholic and 100 non-alcoholic liver disease patients, who were evaluated clinically, Biochemically and confirmed by ultrasonography for liver dysfunction. Out of 100 ALD subjects 91 was male and 9 was female subjects. Whereas in 100 NALD subjects 55 males and 45 females subjects as showed in table 1.

Data of M.G Khan, study conducted that $100 \%$ patients with cirrhosis had lower serum cholinesterase level and he also showed that there was close relationship between the severity of cirrhosis and the level of serum cholinesterase [20]. Another study of O. Ogunkeye et al. also evaluated the low serum cholinesterase level in liver disease patients [21]. Our study also correlates with various studies of scientists who evaluate that Serum cholinesterase values were lowered in all liver disease patients.

Mohd et al. [11]. shows the increased level of 5 ' nucleotidase was seen in liver diseases. When bile stasis occurs, biliary glycosidase cleaves the glycosyl phosphotidyl inositol moiety that anchors ecto-5'NT to the plasma membrane of bile canalicular cells and periportal hepatocyte and second reason given by $\mathrm{F}$. William et al. [22], that detergent action of bile salts may then enable the liberate 5'NT to enter the circulation.

Tarannum F. Subhani [23] et al. study attempted to establish the extent of serum 5'-NT activity in cirrhotic patients and alcohol consumers as compared with normal individuals (controls). This study concluded that the activity of serum $5^{\prime}-\mathrm{NT}$ is consistently higher in cirrhotic patients and alcohol 
consumers, according to the extent of liver damage, hepatobiliary damage, and biliary stasis.

The study of Anil et al. [24] shows the variation of alkaline phosphatase and 5 'NT frequently run parallel to each other in patients with liver disease probably reflects their identical location in liver. but 5 , NT did not increase in bone disease. The study of Varsha Chaudhary et al. [25] also correlates with our study. It concluded that 5' nucleotidase and serum cholinesterase had more sensitivity and specificity to diagnose liver diseases thus 5 ' nucleotidase and serum cholinesterase can distinguish liver diseases from nonliver diseases.

None of single conventional liver function test is important in diagnosis of alcoholic and non-alcoholic liver diseases but when many liver function tests are abnormal at one time, and then there can be probable chance of liver disease. Data of present study clearly states that serum cholinesterase activity alone can be useful to diagnose liver disease. It is cost effective as compared to conventional liver function tests whenever there is need to excluded liver involvement.

\section{CONCLUSION}

It is concluded that there are no single parameters of conventional liver function tests had effective sensitivity and specificity while 5', nucleotidase and serum cholinesterase had more sensitivity and specificity to diagnose alcoholic and non-alcoholic liver disease. Further research is encouraged to determine the efficacy of applying these biomarkers for diagnosis and treatment in a clinical setting and approaching.

\section{REFFERENCE}

1. Sheila, S.H., James, D. "Diseases of the Liver and Biliary System", $11^{\text {th }}$ edn: 2:19-35.

2. Marsano, L.S., Mendez, C., Hill, D., Barve, S., McClain, C.J. (2003). Diagnosis and Treatment of alcoholic liver disease and its complications. Alcohol Research \& Health. 279(3):248-56.

3. Nagato, A. C., Silva, M. A. D. S., Trajano, E. T. L., Alves, J. N., Bandeira, A. C. B., Ferreira, T. A., ... \& Bezerra, F. S. (2011). Quantitative and morphological analyses of different types of human liver. Journal of Morphological Sciences, 28(4), 275-279.

4. Das, S. K., Nayak, P., \& Vasudevan, D. M. (2003). Biochemical markers for alcohol consumption. Indian Journal of clinical biochemistry, 18(2), 111-118.

5. Chakraborti, A. S., Roychowdhury, P., Das, A., \& Mukherjea, M. (1980). A comparative study of 5 'nucleotidase and alkaline phosphatase in human placenta during development. Journal of Biosciences, 2(3), 171-179.
6. Al-Mudhaffar, S. A., \& Saadalla, V. (1978). Kinetics of 5--nucleotidase in sera of liver cirrhotic and normal Iraqi individuals. Biochemistry and experimental biology, 14(4), 339-345.

7. Dinkov, L., Kraĭnikova, M., \& Brailski, K. H. (1979). Serum 5-nucleotidase activity in chronic hepatobiliary diseases. Vutreshni bolesti, 18(1), 39 46.

8. Belfield, A., \& Goldberg, D. M. (1969). Application of a continuous spectrophotometric assay for 5'nucleotidase activity in normal subjects and patients with liver and bone disease. Clinical chemistry, 15(10), 931-939.

9. Rathnakumar, G., \& Raste, A. S. (2000). Can 5 'nucleotidase estimation be a predictor of liver metastases?. Indian journal of cancer, 37(1), $23-$ 26.

10. Storz, G., Imlay, J.A.(1999). Oxidative stress. Curr Opin Microbiol. 2: 188-194.

11. Hyder, M. A., Hasan, M., \& Mohieldein, A. (2016). Comparative Study of 5'-Nucleotidase Test in Various Liver Diseases. Journal of clinical and diagnostic research: JCDR, 10(2), BC01.

12. Turecky, L., Kupcova, V., Mojto, V., Smutny, M., Uhlikova, E., \& Vozar, I. (2005). Serum cholinesterase activity and proteosynthetic function of liver in patients with diabetes mellitus. Bratislavske lekarske listy, 106(8/9), 266.

13. Goldberg, D. M. (1973). 5'nucleotidase: recent advances in cell biology, methodology and clinical significance. Digestion, 8(1), 87-99.

14. Reichling, J.J., Kalpan, M.M. (1988). Clinical use of serum cholinesterase in liver diseases (review): Dis Sci; 33; 16011604 cross ref. Pub Med 1988.

15. Weisinger, R. A. (2000). Laboratory tests in liver disease and approach to the patient with abnormal test. Cecil Textbook of Medicine, 21, 775-776.

16. Vincent, D. (1974). Transaminases, or nithinecarbamyl tranferase, arginase, cholinesterase, etarylesterase. Lyon Med, 232, 267 273.

17. Zhou, X., Tu, Z.G.(2003). Clinical Biological Chemical and Biological Chemical Inspection. 3rd edition, People's Medical Publishing House, Beijing. 325-328.

18. Colovic, M. B., Krstic, D. Z., Lazarevic-Pasti, T. D., Bondzic, A. M., \& Vasic, V. M. (2013). Acetylcholinesterase inhibitors: pharmacology and toxicology. Current neuropharmacology,11(3), 315-335.

19. MCARDLE, B. (1940). The serum choline esterase in jaundice and diseases of the liver. QJM: $A n$ International Journal of Medicine, 9(1), 107-127.

20. Khan, M. G. (1962). The Evaluation of Serum Pseudocholinesterase. The Ulster medical journal, 31(2), 144.

21. Ogunkeye, O. O., Chuhwak, E. K., \& Otokwula, A. A. E. (2010). Serum cholinesterase activity in the 
diagnosis of nonalcoholic fatty liver disease in type 2 diabetic patients. Pathophysiology, 17(1), 29-32.

22. Sunderman, F. W. (1990). The clinical biochemistry of 5'-nucleotidase. Annals of Clinical \& Laboratory Science, 20(2), 123-139.

23. Subhani, T. F., Nasar, M. A., Jarrari, A., D’Souza, V., Naseer, M. A., \& Shakeel, F. (2009). 5'nucleotidase, oxidative stress and antioxidant status in alcohol consumers and cirrhotic patients. Biochemia medica: Biochemia medica, 19(3), 277-286.
24. Anil, B. (2011). Comparative study of serum 5'nucleotidase, alkaline phosphotase, aminotransferase \&bilirubin in alcoholic liver disease. Int. J. Biol. Med Res. 2(1); 436438.

25. Dr. Varsha, C., Dr. G.G. K. (2017). ''Estimation of 5' Nucleotidase and Serum Cholinesterase as Diagnostic Marker to Distinguish Between Various Liver Diseases and Non Liver Diseases" SSRG International Journal of Medical Science (SSRG IJMS),4(8). 